\title{
SEJARAH DAN PERKEMBANGAN KAMPUNG PECINAN DI KOTA MADIUN MASA ORDE LAMA HINGGA REFORMASI (STUDI SOSIAL-EKONOMI)
}

\author{
Rizki Aryono Putro \& Hartono Hadiwasito
}

\begin{abstract}
Abstrak
Penelitian ini bertujuan untuk mengungkap sejarah dan perkembangan kampung Pecinan di Kota Madiun dari masa Orde Lama sampai masa Reformasi. Lokasi penelitian di Kelurahan Pandean Kecamatan Taman Kota Madiun. Dengan memfokuskan pada masyarakat sekitar kampung Pecinan, kondisi kehidupan sosialnya dengan masyarakat Madiun, tradisi-tradisi yang berkembang sampai sekarang ini yang masih dapat dijumpai oleh masyarakat Kota Madiun.

Hasil penelitian menunjukkan bahwa pada masa Orde Lama sistem perekonomian di Indonesia menggunakan sistem perekonomian tertutup, termasuk di Madiun. Pergantian Orde Lama bersamaan yang mengalami perubahan menjadi ekonomi terbuka yang berorentasi kapitalis pada pemerintahan Soeharto. Pemerintah memperkenalkan kebijakan asimilasi yang ditunjukkan pada etnis Cina di Madiun. Pada era Reformasi merupakan masa dimana seluruh rakyat dan khususnya orangorang Cina sebagai warga Indonesia, bebas dan bertanggung jawab untuk menyampaikan aspirasi demi terciptanya kehidupan bangsa yang maju, damai, sejahtera.
\end{abstract}

Kata Kunci: Kampung Pecinan, Orde Lama, Reformasi

*Rizki Aryono Putro adalah alumni Pendidikan Sejarah IKIP PGRI MADIUN

Hartono Hadiwasito Dosen Pendidikan Sejarah IKIP PGRI MADIUN

\section{Pendahuluan}

Indonesia dalam sejarahnya mendapatkan pengaruh dari berbagai kebudayaan karena letaknya yang dilewati jalur pelayaran dan perdagangan. Arus lalu lintas perdagangan dan pelayaran berlangsung melalui jalan darat dan laut. Indonesia yang terletak di jalur posisi silang dua benua dan dua samudera, serta berada di dekat Selat Malaka memiliki keuntungan, yaitu terbuka lebarnya kesempatan menjalin hubungan perdagangan internasional. Bangsa-bangsa asing yang tercatat pernah mengunjungi Indonesia diantaranya adalah Cina, Arab, Persia, Jepang, Spanyol, Portugis, Inggris, dan Belanda.

Jalan Sutra merupakan jalur menghubungkan China dengan negara-negara Asia, Eropa dan Afrika dan memberikan kontribusi yang besar untuk perubahan barang dan interaksi peradaban antara Timur dan Barat. Melalui jalur sutera, pertukaran kebudayaan dan urusan perdagangan antara Timur dan Barat telah dilakukan. Pendapat ini diperkuat oleh Onghokham (1992: 9) bahwa abad ke-17 hubungan pelayaran tetap menghubungkan bangsa- bangsa Asia Tenggara secara 
lebih erat satu sama lain dibandingkan dengan hubungan mereka dengan bangsabangsa dari bagian-bagian dunia lain. Cina dan India sampai pada sebagian besar kawasan ini lewat perdagangan maritim.

Indonesia terkenal akan hasil rempah- rempahnya dan kaya dengan hasil bumi yang dibutuhkan oleh seluruh bangsa Eropa. Rempah- rempah seperti cengkeh, fuli dan kayu manis sebagai bumbu masakan, juga terdapat kamfer, minyak bumi dan beraneka warna daun- daunan dari kepulauan Indonesia yang amat dibutuhkan di Eropa sebagai bahan obat- obatan. Bersamaan dengan barang- barang dagangan dari Asia Tenggara ini ikut pula diangkut hasil kerajinan tangan daratan Cina seperti kain sutra dan barang- barang keramik ( Soekisman, 1975: 17).

Peter Carey menulis, bahwa interaksi orang- orang Tionghoa dan Jawa sudah berlangsung berabad- abad yang lalu lewat perdagangan. Pada masa kejayaan Majapahit (abad ke-14), para bangsawan kerajaan terbiasa berbelanja barangbarang mewah yang diimpor dari negeri Tiongkok, seperti sutera dan porselin. Kecuali itu, beberapa pegawai rendahan (penjaga gerbang tol), orang- orang perahu, dan pedagang- pedagang di sepanjang sungai Berantas, adalah orang- orang keturunan Tionghoa (pecinan) (Rustopo, 2007: 53).

Di beberapa kota di Indonesia, dalam pengaruhnya terhadap kebudayaan Indonesia, Cina memiliki pengaruh yang kuat dan masih dapat dirasakan hingga sekarang. Salah satu daerah di pesisir Jawa yang menjadi daerah persinggahan imigran Cina di Indonesia adalah Kota Semarang. Khawatir akan kekuatan dan keberadaan etnis Tionghoa yang semakin banyak, maka Belanda melancarkan politik perkreditan rakyat dan membuat peraturan sistem pas. Pemerintah membatasi ruang gerak orang Timur Asing. Maka kemana pun mereka pergi, entah untuk keperluan dagang atau untuk bepergian biasa, harus ada surat pas. Sistem ini berarti membatasi kemerdekaan bergerak orang- orang Cina dan merupakan rem bagi kegiatan dagang mereka (Poespoprodjo, 1986: 43).

Masyarakat Cina terus menyebar ke seluruh kota-kota besar dan kecil di seluruh negeri ini. Di daerah-daerah tersebut mereka berbaur dengan penduduk pribumi. Di Madiun orang Cina memiliki tujuan untuk berdagang, bertani, berternak, bahkan ada juga yang menjadi buruh pada perusahaan perusahaan yang ada. Orangorang Cina semakin banyak yang menetap dan ada sebagian yang menikah dengan penduduk lokal. Pada masa kebijakan pemerintahan Belanda memberikan aturan yang sama yang berlaku diseluruh kota- kota di Indonesia termasuk di Madiun, dengan memusatkan seluruh orang-orang Cina di Madiun dalam satu tempat dan mereka membentuk perkampungan yang disebut dengan kampung Pecinan.

Di kampung Pecinan ini orang- orang Cina tinggal dan membuka usaha. Mereka banyak yang berhasil dalam hidupnya, karena Madiun merupakan daerah transit yang memberikan peluang pada orang- orang Cina. Pada masa Orde Lama ternyata mereka masih bertahan dan mampu bersaing dengan penduduk pribumi dalam bidang ekonomi di Madiun, hingga pada masa Reformasi dapat kita lihat mayoritas pertokoan-pertokoan dan tempat usaha- usaha di sekitar Kota Madiun yang menguasai adalah orang-orang Pecinan.

\section{Tinjauan Pustaka}

\section{Kampung Pecinan dan Perkembangannya di Beberapa Daerah di Indonesia}

Menurut Budi A. Sukada (2007: 27), kampung adalah pemukiman pada area kota yang dibentuk oleh konsep keruangan dalam kurun waktu yang 
sangat lama dengan mayoritas masyarakatnya yang homogen. Dengan berkembangnya masyarakat kota makin berkembang pula daerah perkampungan, sehingga batasan kampung itu melebur ke dalam areal kota dan sekarang daerah pemukiman kampung itu menjadi daerah pemukiman kota dimana terjadi proses daya tarik menarik antara sifat homogenitas (kebersamaan yang ada di desa) dengan pluralitas (keserbanekaan di kota) (dalam Herlianto, 1986: 43).

Menurut pendapat Tubagus P. Svarajati (2012: 40) kawasan Pecinan merupakan kawasan medan magnet ekonomi yang kuat. Banyak orang mengail rezeki di kawasan ini. Hal senada diungkapkan Jackson (dalam Pratiwo, 2010: 78) ada tiga karakteristik Pecinan di Asia Tenggara sebagai berikut:

a) batas-batas daerahnya yang jelas yakni dipusat kota dengan karakter yang berbeda dengan lingkungan sekitarnya,

b) terdiri atas kelompok penduduk Tionghoa yang sangat solid dan tidak ada etnis lain yang tinggal di dalamnya. Hampir semua Pecinan di Asia Tenggara memiliki pola jalan grid yang teratur dan garis bangunan ruko yang menerus,

c) merupakan bagian kota yang mana pola hidup dan bermukim terfokus pada tradisi masyarakat Tionghoa, sehingga dunia tersendiri di kota.

Berdasarkan beberapa pendapat di atas dapat disimpulkan pengertian dari kampung Pecinan merupakan pemukiman atau area kelompok rumahrumah yang terletak dikawasan perkotaan dihuni oleh orang-orang Cina, selain dimanfaatkan untuk tempat tinggal kampung Pecinan berfungsi sebagai kawasan perdagangan untuk kelangsungan perekonomian etnis Cina. Keturunan orang-orang Tionghoa di Indonesia melahirkan sekelompok masyarakat Cina yang dapat dikategorikan sebagai golongan minoritas keturunan Cina.

Populasi perkembangan masyarakat Cina tidak terlalu banyak, jika dibandingkan dengan jumlah penduduk di Indonesia. Golongan minoritas ini berusaha untuk melebur manjadi warga setempat yang memiliki pasang-surut sejarah panjang, meski tidak selalu mulus. Pendiskriminasian terhadap golongan etnis Tionghoa atau minoritas Cina dalam perkembangannya di Indonesia terasa sangat memprihatinkan karena adanya sikap rasa tidak senang pada masyarakat lokal terhadap keberadaan golongan minoritas orangorang Cina. Aspek ekonomi umum dianggap sebagai sumber sengketa utama dalam hubungan antara golongan etnis Tionghoa sebagai kelompok minoritas dan masyarakat luas yang mayoritas (Selo Soemardjan, 1988: 196). Begitu juga kehidupan keseharian dalam bidang sosial-ekonomi minoritas orang-orang Cina terus mendapat tekanan. Akibat dari kecemburuan pribumi terhadap tingkat keberhasilan ekonomi orang-orang Cina di sekitar daerahnya.

Akibat dari bentuk politik diskriminasi yang dilakukan secara institusional pada masa Orde Lama di Indonesia ini merupakan penerapan dari ketentuan surat bukti kewarganegaraan Republik Indonesia atau yang populer sekarang ini dengan sebutan SBKRI, terutama ditujukan kepada warga negara Indonesia yaitu etnis Tionghoa. Meskipun ketentuan untuk upaya menempatkan WNI Tionghoa pada status hukum sebagai warga negara Indonesia. Pemerintah Indonesia mengeluarkan peraturan Pemerintah No. 10 tanggal 14 Mei tahun 1959 yang berisi bahwa orang asing di Indonesia di larang 
melakukan usaha dagang kecil dan eceran di luar ibu kota Propinsi dan Kabupaten (Sukisman, 1993: 85).

Tetapi, pada masa Orde Baru dimulai pergantian kebijakan yang baru. Pada kebijakan ini adanya pendiskriminasian di Indonesia. Sehingga menimbulkan kerusuhan-kerusuhan di berbagai tempat di Indonesia antara etnis Tionghoa dengan masyarakat di Indonesia. Menurut pendapat J. Babari dan Albertus Sugeng (1999: 53) kerusuhan yang terjadi pada tanggal 14 April 1994 di Medan antara pemilik pabrik dengan wanita-wanita Cina yang malang dalam jarak dekat dapat merupakan permulaan dari rangkaian bencana selanjutnya. Korbannya setidaknya pedagang mie keturunan Cina dengan penghasilan tidak seberapa, apoteker pada sudut-sudut jalan atau tenaga ahli peranakan di sebuah kantor di jalan Thamrin (Medan). Kejadian-kejadian rasialis setelah Tasikmalaya (1996), Situbondo (1997) dan terutama di Medan dan Pemanukan sekitar tanggal 15 Februari 1998 adalah serentetan kegiatan etnis Cina yang membuktikan kebenaran kalimat terakhir yang telah ditulis pada tahun 1996.

Selain itu terjadi kerusuhan yang terjadi di Jakarta pada tanggal $14 \mathrm{Mei}$ 1998. Kwik Kian Gie (1999: 371) mengemukakan pendapat bahwa pada tanggal 14 Mei 1998 sampai sekitar tiga hari setelah itu, banyak toko yang tutup. Memang benar, banyak barang dagangan yang dijarah, sehingga sebagian tokotoko yang ada di Jakarta tidak mempunyai persediaan lagi. Pendapat serupa dikemukakan Tubagus P. Svarajati (2012: 21) pada bulan Mei 1998 terjadi kerusuhan sebagai tumbalnya orang-orang Cina. Puncak penindasan mutakhir terhadap etnis Cina terjadi pada huru-hara Peristiwa Mei 1998. Dalam catatan menyebutkan, banyak perempuan Cina dinista, diperkosa, dan dibunuh dalam kekacauan saat itu.

\section{Studi Sosial Ekonomi}

Manusia dalam kehidupan di muka bumi, dirasa akan menjalin hubungan dengan dengan manusia. Hubungan ini terjadi secara alami disebabkan sifat manusia cenderung dikehidupan saling membutuhkan dengan manusia lainnya. Maka manusia disebut sebagai makhluk sosial. Ilmu sosial adalah ilmu yang mempelajari manusia dalam hubungannya dengan manusia yang lainnya (Agasty, 2011: 118). Istilah sosial pada ilmu sosial menunjuk pada objeknya, yaitu masyarakat. Di dalam ilmu sosial masyarakat dituju sebagai obyek, disebabkan di dalam masyarakat terjadi interaksi sosial.

Meskipun terdapat perbedaan pendapat mengenai pengertian dari ilmuilmu sosial, namun semua pendapat dari para ahli yang ada di atas semua mengarah kepada pemahaman dan pengertian yang sama. Maka dalam sosial dibutuhkan interaksi sosial antara individu dengan individu yang lain.

Gilin dan Gilin (dalam Dadang Supardan, 2008: 28) memberikan pendapat bentuk umum dalam proses-proses sosial adalah interaksi sosial, bahkan beberapa ahli berpendapat bahwa interaksi sosial tersebut merupakan syarat utama terjadinya aktivitas-aktivitas sosial. Bentuk lain dari prosesproses sosial hanya merupakan bentuk-bentuk khusus dari interaksi sosial. Interaksi sosial merupakan hubungan-hubungan secara perorangan antar kelompok-kelompok manusia, maupun antar perorangan dengan kelompok manusia.

Dalam proses interaksi sosial manusia atau individu membutuhkan komunikasi. Thomas M. Scheidel (dalam Deddy Mulyana, 2007: 4) 
mengemukakan bahwa berkomunikasi untuk menyatakan dan mendukung identitas diri, untuk membangun kontak sosial dengan orang di sekitar kita, untuk mempengaruhi orang lain untuk merasa, berpikir atau berperilaku seperti yang kita inginkan dan untuk mengendalikan lingkungan fisik dan psikologis kita. Melalui komunikasi manusia dapat saling berhubungan antara individu satu dengan individu yang lain, maka manusia mulai membentuk sekelompok manusia yang disebut dengan masyarakat.

Dari beberapa pemaparan pendapat di atas, dapat dijelaskan bahwa ilmu sosial merupakan ilmu yang mengkaji tentang kehidupan manusia untuk dapat berinteraksi dengan manusia yang lain. Dari proses interaksi dikehidupan manusia diperlukan sebuah komunikasi. Maka dalam komunikasi terjadi kesinambungan dalam kurun waktu yang lama. Manusia dalam hidupnya berkelompok dan saling membutuhkan satu sama lain, kemudian dari kelompok-kelompok sosial terciptanya ikatan-ikatan sosial disebut sebagai masyarakat. Pada masyarakat memiliki sifat kontinu dan terikat oleh rasa identitas bersama. Di samping itu dalam hidup bermasyarakat dapat mengalami beberapa perubahan-perubahan sosial. Disebabkan pada masyarakat itu bersifat kontinu selalu mengalami perkembangan, dimana dalam perubahan tersebut dapat terjadi secara lambat maupun cepat.

Manusia dalam hidupnya ingin memenuhi kebutuhannya. Kegiatan ekonomi merupakan suatu hal terpenting dalam usaha memenuhi kebutuhan hidup manusia. Ekonomi merupakan salah satu cabang ilmu pengetahuan yang memiliki peran utama dalam kehidupan manusia. Menurut Winardi (1966: 176) berpendapat bahwa ilmu ekonomi sebuah istilah yang digunakan untuk menunjukkan setiap tindakan atau proses yang bersangkut paut dengan penciptaan barang-barang atau jasa-jasa yang dibuat untuk memenuhi kebutuhan manusia.

Pendapat serupa dikemukakan Ida Bagoes Mantra (2003: 225) semakin memperkuat pendapat-pendapat yang telah ada sebelumnya Usaha tersebut dilakukan dengan mendayagunakan seluruh kemampuan yang dimiliki untuk bekerja. Bekerja diartikan sebagai suatu kegiatan untuk menghasilkan uang barang atau jasa dengan tujuan untuk memperoleh penghasilan berupa uang atau barang dalam kurun waktu tertentu. Maka dengan bekerja seseorang akan menerima hasil dari sebuah usahanya, yaitu uang. Dengan hasil yang diterima dapat untuk memenuhi kebutuhan hidupnya yang bertujuan untuk mencapai kemakmuran dan kesejahteraan.

Pernyataan di atas menjelaskan bahwa ilmu ekonomi mempunyai kaitan dengan ilmu sosial, karena ilmu sosial tidak dapat lepas dari perkembangan ilmu ekonomi. Suherman Rosyidi (2011: 25) mendefinisikan ilmu sosial adalah ilmu tentang manusia serta masyarakat yang sekelompok manusia hidup di dalamnya. Dengan demikian dijelaskan bahwa ilmu ekonomi sebagai subyek, sedangkan masyarakat dijadikan sebagai obyek. Supardi ( 2011: 128) memberikan pendapat yang sama di dalam hubungan antara ekonomi dan sosiologi bahwa ekonomi yang merupakan basis perilaku sosial yang ikut menentukan tipe dan bentuk interaksi mereka. Ekonomi dan material itu memiliki pengaruh atas minat serta motivasi kerja pada masyarakat, dengan memahami perilaku ekonomi suatu masyarakat tidak bisa lepas dari perilaku sosial masyarakat tersebut. 
Berdasarkan beberapa pendapat di atas dapat disimpulkan bahwa ekonomi merupakan ilmu yang mempelajari tentang bagaimana manusia itu dapat memenuhi kebutuhan hidup. Di dalam kehidupan manusia tidak bisa terlepas dengan kegiatan ekonomi, sehingga selalu timbul di dalam kehidupan keseharian manusia. Hal tersebut disebabkan manusia untuk memenuhi kebutuhan hidupnya merasa selalu tidak puas dan tidak terbatas. Maka untuk memenuhi kebutuhan hidupnya baik secara materi dan non materi manusia termotivasi dengan bekerja. Sehingga membuat hidupnya lebih terjamin dan sejahtera.

\section{Metodologi Penelitian}

\section{A. Lokasi Penelitian}

Penelitian ini dilakukan di tengah kota Madiun, tepatnya di Kelurahan Pandean Kecamatan Taman Kota Madiun. Kelurahan Pandean berbatasan dengan Kelurahan Pangongangan yang berada di sebelah utara, Kelurahan Banjarejo berada di sebelah timur, Kelurahan Demangan di sebelah selatan, Kelurahan Nambangan Kidul berada di sebelah barat. Waktu yang digunakan dalam penelitian ini adalah lima bulan, dari bulan Februari sampai dengan bulan Juni tahun 2013.

\section{B. Pendekatan dan Jenis Penelitian}

Penelitian ini menggunakan penelitian kualitatif. Danim (dalam Trianto, 2010: 179) menjelaskan dalam penelitian kualitatif percaya bahwa kebenaran adalah dinamis dan dapat ditemukan hanya melalui penelaahan terhadap orang-orang melalui interaksinya dengan situasi sosial mereka. Adapun pendekatan yang digunakan dalam penelitian ini yaitu fenomenologi. Menurut Bogdan dan Biklen (dalam Asmadi Alsa, 2004: 33) penelitian dengan pendekatan fenomenologi berusaha memahami makna dari suatu peristiwa dan saling pengaruhnya dengan manusia dalam situasi tertentu.

Jenis penelitian yang digunakan dalam penelitian ini adalah penelitian studi kasus. Menurut Foreman (dalam Black A. James dan Champion J. Dean, 2009: 77) penelitian studi kasus menitikberatkan pada suatu pelukisan dari suatu fase atau keseluruhan pengalaman yang relevan dari data tertentu yang dipilih. Apabila perhatian penyelidik dipusatkan pada perkembangan, maka keterengannya adalah sejarah kasus (case history). Pendapat serupa dikemukakan Husaini Usman dan Purnomo Setiady Akbar (2003: 5) penelitian kasus dan penelitian lapangan bermaksud mempelajari secara intensif tentang latar belakang keadaan sekarang, dan interaksi tentang suatu sosial, individu, kelompok, lembaga, dan masyarakat.

\section{Sumber Data, Sampel, Teknik Pengambilan Sampel}

Dalam penelitian kualitatif, antara sumber data satu dengan yang lain saling melengkapi. Sumber data dalam penelitian adalah subjek dari mana data dapat diperoleh (dalam Suharsimi Arikunto, 2010: 172). Sumber data yang digunakan adalah:

a) Sumber data yang bersifat primer

Saifuddin Azwar (2004: 91) berpendapat bahwa, data primer atau data tangan pertama adalah data yang diperoleh langsung dari subjek penelitian dengan mengenakan alat pengukuran atau alat pengambilan data langsung pada subjek sebagai sumber informasi yang dicari. Teknik pengambilan 
sampel yang dipilih yaitu menggunakan snowball sampling (bola salju). Dalam pengambilan datanya melalui observasi dan wawancara.

b) Sumber data yang bersifat sekunder

Data sekunder atau data tangan kedua adalah data yang diperoleh lewat pihak lain, tidak langsung diperoleh oleh peneliti dari subjek penelitiannya (dalam Saifuddin Azwar, 2004: 91). Pengambilan data melalui dokumentasi.

\section{Teknik Keabsahan Data}

Sebelum pelaksanaan analisis data, pada dasarnya data yang sudah terkumpul dari proses wawancara, observasi, serta dokumentasi seluruhnya dimungkinkan tidak sesuai dengan kriteria yang dibutuhkan. Ketidaksesuaian ini dapat menyangkut data yang diperoleh dari sumber primer maupun dari sumber sekunder, kemudian baru di cek keabsahannya. Selanjutnya, merujuk pada validasi sumber untuk menjamin keabsahan dari data yang diperoleh di lapangan. Validasi sumber ini menggunakan teknik Triangulasi. Triangulasi adalah proses penguatan bukti dari individu-individu yang berbeda (Emzir, 2011:82).

\section{E. Teknik Analisis Data}

Pada dasarnya data penelitian yang sudah terkumpul lebih lanjutnya dianalisis untuk diproses menjadi laporan. Analisis data merupakan proses mencari dan menyusun laporan secara sistematis yang diperoleh dari wawancara, observasi dan dokumentasi. Sehingga menghasilkan sebuah tulisan yang mudah dipahami. Analisis data dalam penulisan ini menggunakan analisis interaktif tiga komponen. Tiga komponen utama tersebut adalah (1) Reduksi data, (2) Sajian data, (3) Penarikan simpulan serta verifikasinya. (Miles da Huberman, 1992: 16-19)

\section{Hasil Penelitian}

\section{A. Latar Belakang Keberadaan Kampung Pecinan di Madiun}

Sejak dulu orang Cina di Indonesia dalam mencari nafkah mayoritas berkecipung dalam bidang perdagangan. Di dunia perdagangan mereka memainkan peranan penting sejak beratus-atus tahun yang lalu bahkan sampai sekarang ini. Dalam perdagangannya membutuhkan kurun waktu yang lama di sehingga banyak dari mereka yang tinggal dan berusaha membaur dengan masyarakat pribumi bahkan ada sebagian yang menikah dengan pribumi di Indonesia.

Golongan etnis Cina seringkali diidentikkan sebagai golongan yang memiliki peranan penting dalam perekonomian di Indonesia. Dalam kenyataannya mereka mulai merintis usaha-usaha dibidang perekonomian sejak dahulu dan berhasil, disebabkan adanya beberapa faktor antara lain usaha-usaha orang-orang Cina yang mau bekerja keras, bantuan dana dari kerabat mereka yang berasal dari Negara Cina untuk mengembangkan usahanya di Indonesia, ada lagi faktor yang menunjang dalam menjalankan perdagangan mereka di Indonesia yang berasal dari Pemerintah Hindia Belanda maupun dari pribumi di Indonesia.

Perkembangan orang-orang Cina di Indonesia semakin bertambah, maka banyak dari mereka menyebar keseluruh pelosok kotakota dan membentuk pemukiman-pemukiman untuk dihuni, maka dapat 
disebut sebagai Perkampungan Pecinan. Pada masa penjajahan Belanda perkampungan Cina ditujukan untuk memudahkan pengawasan dalam usaha perdagangan orang-orang Cina. Sehingga banyak dari orang-orang Cina yang mendirikan bangunan tempat tinggal di sekitar pusat kota. Di pusat kota letaknya sangat strategis dekat dengan keramaian, selain itu akses jalan yang mudah untuk menunjang usaha perdagangan mereka (wawancara dengan Endang Wati, 02 Mei 2013). Selain itu, mereka membangun Klenteng diseluruh pelosok di negeri ini. Klenteng merupakan tempat peribadatan bagi umat beragama Khonghucu untuk menjalin hubungan religi dengan Sang Pencipta.

Madiun merupakan kota yang terletak di Provinsi Jawa Timur menjadi salah satu kota yang memiliki bangunan Klenteng. Sekitar tahun 1870 Belanda memberikan kesempatan pada orang Asing untuk membuka usaha atau berinvestasi. Salah satunya adalah orang Cina yang memiliki tujuan untuk berdagang, bahkan ada sebagian kecil dari orang-orang Cina yang bertani, berternak, menjadi buruh pada perusahaan perusahaan yang ada di Madiun. Sehingga dengan bertambahnya orang-orang Cina di Madiun, kemudian Belanda menentukkan pemukiman untuk orang-orang Cina. Perkampungan Pecinan tersebut terletak di dekat Pasar Besar Madiun dan Pasar Sleko, tepatnya berada di daerah Jl. Barito (dulunya bernama Gang Tengah), Jl. Agus Salim, Jl. Kutai, sekitar Pasar Sleko. Selanjutnya mereka membangun Kuil di Madiun yang pertama kali di sebelah barat sungai Madiun sebagai tempat untuk berhubungan dengan Yang Maha Kuasa lewat sembahyang.

Adapun sejarah singkat Klenteng yang berada di Madiun. Pada tahun 1887 Madiun masih dibawah kepemimpinan Residen Belanda. Ketika itu istri dari Residen tersebut menderita suatu penyakit yang tak kunjung sembuh, bahkan dokter tidak sanggup menanganinya dan menyarankan untuk pergi ke negeri Belanda. Tetapi tidak mungkin karena membutuhkan waktu yang lama untuk menempuh perjalanan, sedangkan melihat kondisi istri untuk melakukan perjalanan jauh amat tidak mungkin. Maka berita sakitnya istri seorang Residen Belanda tersebar ke masyarakat. Kapiten Liem Koen Tie (Ketua Masyarakat Tionghoa Madiun) ternyata mendengar berita tersebut dan menghadap kepada Residen Belanda untuk membantu kesembuhan istri beliau. Kemudian Kapiten Liem Koen Tie memberikan saran kesembuhan untuk memohon kesembuhan kepada Yang Mulia Ma Co Po Thian Siang Seng Boo dan Residen menuruti atas sarannya.

Selanjutnya, Kapiten Liem Koen Tie memohon melalui Jian Si untuk mendapatkan resep obat dan diminumkan ke istri Residen. Pada saat malam hari Residen Belanda bermimpi bertemu dengan sosok wanita yang memakai pakaian Aristokrat Tionghoa dan memberikan pesan bahwa istrinya tidak lama lagi akan sembuh dan ternyata setelah rutin meminum obat selama satu minggu istri Residen menjadi sembuh. Melihat istrinya sudah sembuh total, kemudian Residen memberikan sebidang tanah seluas $\pm 10.000 \mathrm{M}^{2}$, untuk dibangun kuil sebagai tempat sembahyang yang terletak sampai sekarang di jalan Cokroaminoto.

Selama pembangunannya ini mendapatkan pengawasan dan perhatian dari Residen. Dalam proses pembangunan kuil, beliau memberikan keramik-keramik yang didatangkan dari Belanda. Proses 
pembangunan itu dipimpin oleh Kapiten Liem Koen Tie dibantu dengan Bp. Tan Ing ju, Bp. Tan Bik Swat, Bp. Njou Kie Siong, Bp. Njoo Kie San, Bp. Liem Kwang Piau, Bp. Gwe Kwie Tiong dan bersama-sama dengan masyarakat Tionghoa. Desain bangunan mendatangkan arsitek dari daerah Hokkian Tiongkok, serta lantai berasal dari Tiongkok. Melalui kesepakatan bersama Klenteng tersebut meniru model khas Tiongkok.

B. Gambaran Umum Kampung Pecinan di Madiun Pada Masa Orde Lama Sampai Dengan Reformasi Di Madiun.

a) Pada Masa Orde Lama

Pada masa Orde Lama sistem perekonomian di Indonesia menggunakan sistem perekonomian tertutup, yang menerapkan kebijakan untuk pembatasan adanya investasi Asing yang masuk di dalam negeri, bahkan pada bidang perdagangan adanya pembatasan barangbarang yang berasal dari luar negeri. Sikap seperti ditujukan kepada orang-orang Cina yang tinggal di Indonesia.

Pemerintah pada masa Orde Lama melakukan pengawasan terhadap pemberian izin usaha memproduksi barang, hak usaha grosir dan dalam bidang perdagangan. Sikap seperti ini bertujuan untuk menguntungkan pihak pribumi. Selain itu kegiatan-kegiatan usaha dagangnya mendapatkan beberapa gangguan. Ketika itu pernah terjadi pembakaran terhadap salah satu toko usaha dagang orang Cina yang berada di Madiun yang terletak di Jl. Trunojoyo. Orang-orang yang membakar toko usaha dagang milik Cina adalah orang-orang yang berasal dari luar kampung ini, sedangkan penduduk pribumi yang mendiami kampung ini mereka selalu menjaga bersama-sama dengan orang Cina yang juga tinggal di kampung ini (wawancara dengan Poerwoto, $01 \mathrm{Mei}$ 2013).

Selanjutnya, sekitar tahun 1950 diberlakukan politik asli yang bertujuan memperkecil kekuatan ekonomi etnis Tionghoa di Indonesia. Berbagai peraturan yang memberikan hak-hak istimewa kepada pengusaha pribumi dan perlindungan yang diberikan kepada perusahaan-perusahaan nasional yang perusahaannya memiliki saham sebagian besar dimiliki pribumi. Tindakan diskriminasi terutama ditujukan terhadap orang-orang Asing yang tinggal di Indonesia dan khususnya dilakukan pada etnis Cina, tindakan seperti sering disebut dengan sistem Benteng. Sistem Benteng ini untuk melindungi persaingan usaha perdagangan antara pengusaha-pengusaha pribumi dengan pengusaha-pengusaha Asing.

Sebaliknya keadaan sosial-ekonomi yang terjadi di Madiun tidaklah se-ekstrim seperti yang terjadi di kota-kota lain yang ada di Indonesia misalnya Jakarta, Solo, Semarang. Untuk masyarakat Madiun di sekitar kampung Pecinan terjadi hubungan yang damai dan harmonis. Orang-orang Cina yang menempati kampung ini mereka dapat membaur dengan masyarakat pribumi, sehingga tidak pernah terjadi konflik antara pribumi dengan orang-orang Cina di Madiun. Hal ini disebabkan orangorang Cina yang tinggal di Madiun mau menghargai adat atau kebiasaan yang ada di dalam masyarakat, misalnya acara slametan, acara kematian dan acara pernikahan, mereka ikut berpartisipasi datang dan membaur dengan masyarakat pribumi. Hal yang sama juga dilakukan pada etnis 
Cina, apabila mereka sedang mengadakan acara juga mengundang orangorang pribumi untuk datang dalam acara tersebut. Maka dalam urusan usaha perdagangan di Madiun dengan etnis Cina terjadi persaingan yang sehat, disebabkan adanya sikap toleransi, simpati dan kebersamaan dalam hidup bermasyarakat (Tri Yudi Ernawati, 28 April 2013).

Pendek kata, di kampung Pecinan tepatnya di jalan Barito yang dulunya bernama Gang Tengah merupakan pusat perdagangan orangorang Cina. Di jalan Barito merupakan pusat diproduksinya beranekaragam roti. Sebagian besar orang-orang Cina yang mendiami sekitar kawasan ini mendirikan usaha-usaha roti sebagai peluang dalam mencari nafkah. Sehingga sampai sekarang ini usaha-usaha roti atau tepatnya home industri roti masih bertahan di sekitar jalan Barito. Masyarakat pribumi dengan orang-orang Cina hidup berdampingan secara rukun dan mereka hidup saling bekerjasama dalam kebersihan dan keamanan lingkungan tempat tinggalnya (wawancara dengan Rudy Suwanto, 29 April 2013). Maka dengan adanya dukungan dari masyarakat sekitar banyak orang-orang Cina yang membuka usaha dagang di sekitar Jalan Kutai, Jalan Cokroaminoto, Jalan Agus Salim. Kemudian mereka tidak membuka usaha roti, tetapi mulai mengembangkan usaha-usaha yang lain seperti menjual bahan kebutuhan pokok.

b) Pada Masa Orde Baru

Tahun 1966 terjadi pergolakan politik yang hebat di Indonesia, yaitu pergantian Orde, dimana telah terjadi pergantian dari Orde lama ke Orde baru. Pergantian Orde Lama bersamaan dengan runtuhnya suatu rezim, yaitu rezim Soekarno, yang dulunya di dalam kebijakan ekonomi mengalami ketertutupan yang berorentasi sosialis kemudian mengalami perubahan menjadi ekonomi terbuka yang berorentasi kapitalis pada pemerintahan Soeharto. Pemerintahan pada masa Orde baru merupakan pemerintahan yang mendapat dukungan dari kekuatan militer dan mendapat simpatikan dari kelompok borjuis. Prioritas yang paling utama adalah pengendalian inflasinya dari pertumbuhan ekonomi yang tinggi.

Hal ini berdampak juga pada kondisi sosial-ekonomi masyarakat Indonesia, juga kondisi seperti ini berpengaruh pada penduduk di Madiun. Dengan adanya perubahan kebijakan pemerintahan menguntungkan pihak-pihak yang kuat ekonominya atau dalam kategori orang-orang kaya yang memiliki usaha yang maju, sedangkan untuk masyarakat ditingkat rendah mengalami kondisi yang sangat tertekan. Pada masa Orde Baru yang berjaya selama tiga dekade lebih, selama itu pula etnis Cina banyak mengalami diskriminasi. Selain itu pemerintah memperkenalkan kebijakan asimilasi yang ditunjukkan pada etnis Cina. Bagi orang-orang Cina yang tinggal di Madiun mereka juga merasakan kebijakan tersebut dari pemerintah pusat, bahwa di dalam kebijakan tersebut pemerintah melarang semua yang berkaitan dengan Cina, seperti bahasa Cina, adat atau kebudayaan Cina yang masuk di Indonesia harus di hapus.

Adanya persepsi seperti ini, dapat dimengerti bahwa pemerintah Orde Baru berusaha mendiskriminasikan orang-orang Cina dan memberikan tekanan-tekanan terhadap mereka. Dahulu di Madiun ada sekolah Cina yang terletak di jalan Cokroaminoto depan Klenteng dan 
di jalan Agus Salim yang sekarang digunakan sebagai Perpustakaan Umum Madiun, tetapi setelah adanya kebijakan asimilasi terhadap etnis Cina sekolah-sekolah Cina yang berada di Madiun diambil alih oleh pemerintah. Hal ini merupakan salah satu tekanan dari pemerintah pada bidang pendidikan (wawancara dengan Lianawati, 27 April 2013).

Aspek kebudayaan Cina yang ada di Madiun, yaitu budayabudaya Cina dan bahasa Cina mendapat diskriminasi oleh pemerintah. Hal ini disebabkan adanya kebijakan asimilasi dari pemerintah Orde Baru pada etnis Cina, termasuk kebudayaan Barongsai dan wayang Tiongkok merupakan hasil kebudayaan asli dari Cina yang dilarang untuk ditampilkan dan diperkenalkan pada masyarakat Madiun.

Pendek kata, kondisi yang terjadi pada orang-orang Cina pada masa pemerintahan Soeharto adalah salah satu kebijakan yang diterapkan di Indonesia, yaitu proses naturalisasi yang ditujukan kepada seluruh orang-orang Cina yang bertempat tinggal lama di Indonesia, termasuk di Madiun. Pada proses naturalisasi ini orang-orang Cina mengganti nama asli mereka dengan nama-nama Indonesia atau namanama pribumi, misalnya seperti nama Ang Ciak Jun berganti nama Rudy Siswanto (wawancara dengan Rudy Siswanto, 29 April 2013).

Selanjutnya, pada proses naturalisasi ini membutuhkan dana atau biaya yang cukup besar, sehingga banyak dari orang-orang Cina di Madiun yang ekonominya rendah tidak dapat melanjutkan proses naturalisasi disebabkan kebentur dengan besarnya biaya yang dikeluarkan. Sehingga masih banyak dari mereka yang belum dapat bernaturalisasi di Madiun.

Bulan Mei 1998 di Jakarta dan Solo terjadi kerusuhan yang sangat hebat, dimana dalam kerusuhan itu yang menjadi salah satu korbannya adalah orang-orang Cina. Peristiwa ini terjadi bertujuan untuk meruntuhkan suatu rezim pada masa itu, yaitu rezim Soeharto. Banyak usaha-usaha atau pertokoan-pertokoan yang didirikan etnis Cina dibakar, dirusak, dihancurkan. Adapun bentuk kekerasan fisik dan penindasan terhadap orang-orang Cina yaitu pemerkosaan, pemerasan.

Sebaliknya, keadaan di Madiun justru tidak se-ekstrim yang terjadi di kota-kota besar di Indonesia. Kondisi di Madiun terasa aman dan tidak ada satupun kericuhan dengan penduduk pribumi, tetapi hanya mendapatkan imbas dari peristiwa tersebut, itupun hanya satu hari saja. Di Madiun imbas dari peristiwa Mei 1998 tempat-tempat dagang atau pertokoan-pertokoan milik usaha Cina banyak yang tutup di sepanjang jalan Madiun, namun masih ada sebagian toko yang tetap buka. Sebab Madiun tidak mengalami kerusuhan seperti yang terjadi di Jakarta dan Solo dikarenakan di Madiun sendiri militernya sangat kuat, yang diperkuat oleh angkatan darat dan udara yang ada di sekitar Madiun. Sehingga keadaan di Madiun sangat aman pada waktu peristiwa Mei 1998 (wawancara dengan Pramono, 06 Mei 2013).

c) Pada Masa Reformasi

Runtuhnya rezim Soeharto yang terjadi pada masa Orde Baru melahirkan suatu babak baru bagi Indonesia. Terjadi perubahan yang besar terhadap bentuk dan arah pemerintahan. Otoritas penguasa semakin terhimpit dengan merebaknya semangat demokrasi di 
Indonesia. Reformasi merupakan sebuah masa di mana terjadi perombakan dalam tubuh pemerintahan yang semula bersifat semi absolut atau militeristik menjadi pemerintahan yang berasaskan demokrasi, sehingga masyarakat dapat menyalurkan aspirasinya secara bebas dan bertanggung jawab. Masa reformasi ini berlangsung sejak tahun 1998 hingga sekarang.

Gema Reformasi yang melanda Indonesia ikut memberikan dampak terhadap kehidupan masyarakat Madiun. Hal tersebut tampak pada keberadaan etnis Cina di Madiun yang semakin memiliki aksesbilitas yang tinggi apabila dibandingkan dengan masa Orde Baru. Etnis Cina di Madiun dapat leluasa mengembangkan usaha-usaha yang telah dirintis secara turun-menurun. Semasa kepemimpinan Soeharto mempersempit ruang gerak orang-orang Cina selama di Indonesia, termasuk dalam bidang pendidikan, sosial-budaya mendapatkan diskriminasi. Bagi etnis Cina ini merupakan angin segar setelah runtuhnya rezim Soeharto selama tiga dekade.

Masa Reformasi merupakan masa dimana seluruh rakyat dan khususnya orang-orang Cina sebagai warga Indonesia, bebas dan bertanggung jawab untuk menyampaikan aspirasi demi terciptanya kehidupan bangsa yang maju, damai, sejahtera. Ketika pemerintahan Indonesia digantikan dengan Gus Dur atau Abdurahman Wahid. Bagi orang-orang Cina di Indonesia merupakan sebuah cahaya yang terang, disebabkan pada masa pemerintahan Gus Dur menghapus larangan hakhak etnis Cina untuk kembali memperkenalkan adat dan kebudayaan asli negara Cina (wawancara dengan Suwarno, 24 April 2013).

Selanjutnya, Presiden Gus Dur mengakui agama Khong $\mathrm{Hu} \mathrm{Cu}$ yang masuk di Indonesia merupakan sebagian besar agama yang ada di Indonesia. Sebab itu banyak orang-orang Cina yang ada di Madiun mempopulerkan Gus Dur selama menjabat menjadi Presiden. Dengan diberikannya kesempatan untuk mengekspresikan identitas kebudayaan mereka, secara tidak langsung pemerintah sebenarnya memberikan kesempatan kepada orang-orang Cina untuk berpartisipasi dalam pembangunan Indonesia (wawancara dengan Rudy Suwanto, 29 April 2013).

Pendek kata, pemerintah Gus Dur sudah membuka jalan bagi orang-orang Cina untuk menunjukkan identitas kebudayaan Cina di Indonesia. Melalui kebudayaan asli dari Cina, seperti Barongsai dan wayang Tiongkok mulai diperkenalkan pada masyarakat Indonesia. Di Madiun dalam pertunjukkan kesenian Barongsai masyarakatnya memiliki antusias yang tinggi pada waktu kesenian ini ditampilkan. Sehingga sampai sekarang ini kesenian Barongsai yang ada di Madiun tetap dilestarikan, pada acara-acara tertentu Madiun seringkali menampilkan kesenian Barongsai dan melibatkan orang-orang Jawa pada saat pertunjukkan.

Kesenian Barongsai semenjak pemerintahan Gus Dur sampai sekarang ini mengalami banyak perkembangan. Dalam kesenian Barongsai sekarang ini juga dapat dipelajari oleh anak bangsa Indonesia, tidak hanya orang-orang Cina saja yang mempelajarinya. Di Madiun untuk mempelajari kesenian Barongsai bisa mendapatkan latihan di Klenteng 
yang berada di jalan Cokroaminoto, bahkan dalam perkembangannya di Madiun kesenian Barongsai juga sudah masuk di kalangan Pondok Pesantren yang ada di Kecamatan Taman Kelurahan Demangan yang bernama Pondok Pesantren Mujaddadiyah, cabang dari Pondok Pesantren ini juga terletak di Kecamatan Kare. Selain kesenian Barongsai kebudayaan Cina yang masuk di Indonesia, yaitu wayang Tiongkok dalam ulang tahun Klenteng ditayangkan selama satu bulan penuh, makanan khas Cina yang disajikan pada saat ulang tahun Klenteng Madiun misalnya Ca Kwe, Kue Goreng, Bakpao yang disajikan untuk kalangan masyarakat umum Madiun secara gratis (wawancara dengan Pramono, 06 Mei 2013).

Berakhirnya kepemimpinan Presiden Abdurahman Wahid atau Gus Dur, pemerintahan Indonesia digantikan dengan Megawati Soekarno Putri. Pada masa pemerintahan Megawati mulai menetapkan tahun baru Imlek sebagai hari libur nasional di Indonesia. Implek merupakan tahun baru bagi kebudayaan Cina, dimana dalam perayaannya dirayakan sangat meriah. Khususnya di Madiun sendiri dalam perayaan malam Tahun baru Implek dirayakan di Klenteng atau tempat peribadatan Tri Dharma.

Selanjutnya, malam perayaan terdapat Lampion-Lampion untuk menghiasi suasana saat malam sebagai adat atau ciri khas dari budaya Cina. Sehingga menjadi suguhan yang menghibur masyarakat Madiun, juga pada sore hari sebelum acara tahun baru sering menampilkan pertunjukkan kesenian Barongsai (wawancara dengan Sucipto, 24 April 2013).

Di era Reformasi memberikan pengaruh di sektor perekonomian Madiun. Banyak dari orang-orang keturunan Cina mulai mengembangkan beberapa usahanya yang sudah berjalan di Madiun. Banyak keturunan etnis Cina yang berhasil dalam meningkatkan usahausahanya di Madiun. Hal ini dapat dibuktikan di daerah kawasan Pecinan yang ada di Madiun berfungsi sebagai tempat untuk berdagang dan mendirikan usaha-usaha. Sebagian besar perekonomian di Madiun sekarang ini didominasi oleh keturunan orang-orang Cina di bidang usaha atau perdagangan.

Secara singkat, perkembangan kampung Pecinan di masa sekarang sudah banyak bercampur dengan masyarakat dari berbagai macam etnis seperti Arab, Madura, Jawa, bahkan mereka juga melakukan perkawinan dengan orang-orang pribumi. Semakin berkembangnya tingkat pengetahuan di masyarakat, serta tuntutan dalam memenuhi kebutuhan hidup, di kampung Pecinan ini banyak orang-orang Cina yang mulai mengembangkan usahanya di luar kampung Pecinan dan ada sebagian masyarakatnya yang pindah ke daerah lain atau luar kota untuk mencoba merintis usahanya (wawancara dengan Andre Pramusinto, 24 April 2013).

Perkampungan Pecinan Madiun di Kecamatan Taman di Kelurahan Pandean pada masa Reformasi tidak hanya terpusat di daerah jalan Barito, jalan Kutai, jalan Cokroaminoto, jalan Agus Salim, dan jalan Trunojoyo, namun sekarang ini sudah menyebar di seluruh kawasan di daerah Madiun. Di kawasan Pecinan sekarang ini masyarakatnya sudah homogen, tidak bisa dikategorikan sebagai kampung Pecinan murni. 


\section{Pembahasan}

\section{A. Sejarah Keberadaan Kampung Pecinan di Madiun}

Di dunia perdagangan semenjak dahulu etnis Cina memainkan peranan penting sejak beratus-atus tahun yang lalu bahkan sampai saat ini. Tujuan kedatangannya di Indonesia melakukan hubungan dagang dengan pribumi. Perdagangannya etnis Cina menyebar seluruh pelosok negeri dan membutuhkan kurun waktu yang lama, sehingga banyak dari mereka yang tinggal dan berusaha membaur dengan masyarakat pribumi bahkan ada sebagian yang menikah dengan pribumi di Indonesia.

Etnis Cina identik sebagai golongan yang memiliki peranan penting dalam perekonomian di Indonesia. Melalui kenyataannya mereka mulai merintis usaha-usaha dibidang perekonomian sejak dahulu dan berhasil, disebabkan adanya beberapa faktor antara lain usaha-usaha orang-orang Cina yang mau bekerja keras, bantuan dana dari kerabat mereka yang berasal dari Negara Cina untuk mengembangkan usahanya di Indonesia. Perkembangan orang-orang Cina di Indonesia semakin bertambah, maka banyak dari mereka menyebar keseluruh pelosok kota-kota dan membentuk pemukimanpemukiman untuk dihuni, maka dapat disebut sebagai Perkampungan Pecinan. Orang-orang Cina yang datang di Madiun merupakan orang keturunan Cina atau dapat dikategorikan sebagai Cina Peranakan di Indonesia yang datang dari berbagai daerah di Indonesia, misalnya Solo, Sragen, Kalimantan (wawancara dengan Bapak Pramono, 06 Mei 2013).

Pada masa penjajahan Belanda perkampungan Cina ditujukan untuk memudahkan pengawasan dalam usaha perdagangan orang-orang Cina. Sehingga banyak dari orang-orang Cina yang mendirikan bangunan tempat tinggal di sekitar pusat kota. Bentuk bangunannya sekarang ini masih dapat ditemui. Bentuk rumah di depan muka rumah terdapat toko. Rumah tidak terlalu lebar, tetapi memanjang ke belakang. Pola pemukimannya saling berhadap-hadapan dan memanjang sepanjang jalan. Di pusatkan dikota letaknya sangat strategis dekat dengan keramaian, selain itu akses jalan yang mudah untuk menunjang usaha perdagangan mereka.

Politik Pintu Terbuka yang diperundang-undangkan sejak tahun 1870 yang menanamkan modalnya di Madiun bukan hanya Belanda, tetapi Belanda memberikan kesempatan pada orang Asing untuk membuka usaha atau berinvestasi (Pemerintah Kabupaten Daerah Tingkat II Madiun, 1980: 212). Madiun merupakan kota yang terletak di Provinsi Jawa Timur menjadi salah satu kota yang memiliki bangunan Klenteng. Salah satunya adalah orang Cina yang memiliki tujuan untuk berdagang, bahkan ada sebagian kecil dari orangorang Cina yang bertani, berternak, menjadi buruh pada perusahaan perusahaan yang ada di Madiun. Sehingga dengan bertambahnya orang-orang Cina di Madiun, kemudian Belanda menentukkan pemukiman untuk orangorang Cina.

Perkampungan Pecinan tersebut terletak di dekat Pasar Besar Madiun dan Pasar Sleko, tepatnya berada di daerah Jl. Barito (dulunya bernama Gang 
Tengah), Jl. Agus Salim, Jl. Kutai, sekitar Pasar Sleko. Selain itu, mereka membangun Klenteng diseluruh pelosok di negeri ini. Klenteng merupakan tempat peribadatan bagi umat beragama Khonghucu untuk menjalin hubungan religi dengan Sang Pencipta. Mereka membangun Kuil di Madiun yang pertama kali di sebelah barat sungai Madiun sebagai tempat untuk berhubungan dengan Yang Maha Kuasa lewat sembahyang.

Adapun sejarah singkat Klenteng yang berada di Madiun. Pada tahun 1887 Madiun masih dibawah kepemimpinan Residen Belanda. Ketika itu istri dari Residen tersebut menderita suatu penyakit yang tak kunjung sembuh, bahkan dokter tidak sanggup menanganinya dan menyarankan untuk pergi ke negeri Belanda. Tetapi tidak mungkin karena membutuhkan waktu yang lama untuk menempuh perjalanan, sedangkan melihat kondisi istri untuk melakukan perjalanan jauh amat tidak mungkin. Maka berita sakitnya istri seorang Residen Belanda tersebar ke masyarakat. Kapiten Liem Koen Tie (Ketua Masyarakat Tionghoa Madiun) ternyata mendengar berita tersebut dan menghadap kepada Residen Belanda untuk membantu kesembuhan istri beliau. Kemudian Kapiten Liem Koen Tie memberikan saran kesembuhan untuk memohon kesembuhan kepada Yang Mulia Ma Co Po Thian Siang Seng Boo dan Residen menuruti atas sarannya. setelah rutin meminum obat selama satu minggu istri Residen menjadi sembuh. Melihat istrinya sudah sembuh total, kemudian Residen memberikan sebidang tanah seluas $\pm 10.000 \mathrm{M}^{2}$, untuk dibangun kuil sebagai tempat sembahyang yang terletak sampai sekarang di jalan Cokroaminoto.

Selanjutnya, selama pembangunannya ini mendapatkan pengawasan dan perhatian dari Residen. Dalam proses pembangunan kuil, beliau memberikan keramik-keramik yang didatangkan dari Belanda. Proses pembangunan itu dipimpin oleh Kapiten Liem Koen Tie dibantu dengan Bp. Tan Ing ju, Bp. Tan Bik Swat, Bp. Njou Kie Siong, Bp. Njoo Kie San, Bp. Liem Kwang Piau, Bp. Gwe Kwie Tiong dan bersama-sama dengan masyarakat Tionghoa. Desain bangunan mendatangkan arsitek dari daerah Hokkian Tiongkok, serta lantai berasal dari Tiongkok. Melalui kesepakatan bersama Klenteng tersebut meniru model khas Tiongkok.

\section{B. Perkembangan Kampung Pecinan Pada Masa Orde Lama Sampai Dengan Reformasi Di Madiun (Studi Sosial Ekonomi)}

a) Perkembangan Pada Masa Orde Lama

Setelah Indonesia resmi merdeka dari penjajahan bangsa lain pada tanggal 17 Agustus tahun 1945, maka dibentuk pemerintah baru di Indonesia dan dipilih Kepala Pemerintah Republik Indonesia yaitu Ir. Soekarno. Beliau merupakan Presiden Republik Indonesia yang pertama. Pada masa ini Indonesia mengalami carut marut dalam sektor ekonomi, karena baru merdeka. Leo Suryadinata (1990: 162) dalam tajuk rencana kompas mendukung adanya sistem ekonomi yang berencana untuk mengatasi ketidakseimbangan perkembangan sektor agraris yang slow moving dan sektor industri yang smooth-running.

Pada masa Orde Lama sistem perekonomian di Indonesia menggunakan sistem perekonomian tertutup, yang menerapkan kebijakan untuk pembatasan adanya investasi Asing yang masuk di dalam negeri, bahkan pada bidang perdagangan adanya pembatasan barang-barang yang 
berasal dari luar negeri. Sikap seperti ditujukan kepada orang-orang Cina yang tinggal di Indonesia.

Pemerintah pada masa Orde Lama melakukan pengawasan terhadap pemberian izin usaha memproduksi barang, hak usaha grosir dan dalam bidang perdagangan. Sikap seperti ini bertujuan untuk menguntungkan pihak pribumi. Selain itu kegiatan-kegiatan usaha dagangnya mendapatkan beberapa gangguan.

Di Madiun pada masa PKI 1948 pernah terjadi pembakaran terhadap salah satu toko usaha dagang orang Cina yang berada di Madiun yang terletak di Jl. Trunojoyo. Orang-orang yang membakar toko usaha dagang milik Cina adalah orang-orang yang berasal dari luar kampung ini, sedangkan penduduk pribumi yang mendiami kampung ini mereka selalu menjaga bersama-sama dengan orang Cina yang juga tinggal di kampung ini (wawancara dengan Poerwoto, 01 Mei 2013).

Selanjutnya, Tahun 1950 diberlakukan politik asli yang bertujuan memperkecil kekuatan ekonomi (terutama dalam bidang komersial) etnis Tionghoa di Indonesia. Berbagai peraturan yang memberikan hak-hak istimewa kepada pengusaha pribumi (misalnya sistem Benteng) dan perlindungan yang diberikan kepada perusahaan-perusahaan nasional yang didefinisikan sebagai perusahaan yang sahamnya sebagian besar dimiliki pribumi (Leo Suryadinata, 1999: 121). Tindakan diskriminasi terutama ditujukan terhadap orang-orang Asing yang tinggal di Indonesia dan khususnya dilakukan pada etnis Cina, tindakan seperti sering disebut dengan sistem Benteng. Sistem Benteng ini untuk melindungi persaingan usaha perdagangan antara pengusaha-pengusaha pribumi dengan pengusaha-pengusaha Asing.

Sebaliknya, keadaan sosial-ekonomi yang terjadi di Madiun tidaklah se-ekstrim seperti yang terjadi di kota-kota lain yang ada di Indonesia misalnya Jakarta, Solo, Semarang. Untuk masyarakat Madiun di sekitar kampung Pecinan terjadi hubungan yang damai dan harmonis. Orang-orang Cina yang menempati kampung ini mereka dapat membaur dengan masyarakat pribumi, sehingga tidak pernah terjadi konflik antara pribumi dengan orang-orang Cina di Madiun. Hal ini disebabkan orangorang Cina yang tinggal di Madiun mau menghargai adat atau kebiasaan yang ada di dalam masyarakat, misalnya acara slametan, acara kematian dan acara pernikahan, mereka ikut berpartisipasi datang dan membaur dengan masyarakat pribumi.

Etnis Cina juga melakukan hal yang sama, apabila mereka sedang mengadakan acara juga mengundang orang-orang pribumi untuk datang dalam acara tersebut. Maka dalam urusan usaha perdagangan di Madiun dengan etnis Cina terjadi persaingan yang sehat, disebabkan adanya sikap toleransi, simpati dan kebersamaan dalam hidup bermasyarakat.

Pendek kata, di kampung Pecinan tepatnya di jalan Barito yang dulunya bernama Gang Tengah merupakan pusat perdagangan orangorang Cina. Di jalan Barito merupakan pusat diproduksinya beranekaragam roti. Sebagian besar orang-orang Cina yang mendiami sekitar kawasan ini mendirikan usaha-usaha roti sebagai peluang dalam mencari nafkah. Sehingga sampai sekarang ini usaha-usaha roti atau tepatnya home industri roti masih bertahan di sekitar jalan Barito. Masyarakat pribumi 
dengan orang-orang Cina hidup berdampingan secara rukun dan mereka hidup saling bekerjasama dalam kebersihan dan keamanan lingkungan tempat tinggalnya. Maka dengan adanya dukungan dari masyarakat sekitar banyak orang-orang Cina yang membuka usaha dagang di sekitar Jalan Kutai, Jalan Cokroaminoto, Jalan Agus Salim. Kemudian mereka tidak membuka usaha roti, tetapi mulai mengembangkan usaha-usaha yang lain seperti menjual bahan kebutuhan pokok.

b) Perkembangan Pada Masa Orde Baru

Tahun 1966 terjadi pergolakan politik yang hebat di Indonesia, yaitu pergantian Orde, dimana telah terjadi pergantian dari Orde lama ke Orde baru. Pergantian Orde Lama bersamaan dengan runtuhnya suatu rezim, yaitu rezim Soekarno, yang dulunya di dalam kebijakan ekonomi mengalami ketertutupan yang berorentasi sosialis kemudian mengalami perubahan menjadi ekonomi terbuka yang berorentasi kapitalis pada pemerintahan Soeharto. Pemerintahan pada masa Orde baru merupakan pemerintahan yang mendapat dukungan dari kekuatan militer dan mendapat simpatikan dari kelompok borjuis. Prioritas yang paling utama adalah pengendalian inflasinya dari pertumbuhan ekonomi yang tinggi.

Hal ini berdampak juga pada kondisi sosial-ekonomi masyarakat Indonesia, juga kondisi seperti ini berpengaruh pada penduduk di Madiun. Dengan adanya perubahan kebijakan pemerintahan menguntungkan pihak-pihak yang kuat ekonominya atau dalam kategori orang-orang kaya yang memiliki usaha yang maju, sedangkan untuk masyarakat ditingkat rendah mengalami kondisi yang sangat tertekan. Pada masa Orde Baru yang berjaya selama tiga dekade lebih, selama itu pula etnis Cina banyak mengalami diskriminasi.

Pemerintah memperkenalkan kebijakan asimilasi yang ditunjukkan pada etnis Cina. Leo Suryadinata, Evi Nurvidya Arifin, Aris Ananta (2003: 78) mengemukakan bahwa ada tiga pilar budaya Tionghoa yaitu organisasi Tionghoa, media Tionghoa dan sekolah Tionghoa dilarang pemerintah dan orang Tionghoa harus di Indonesiakan atau dipribumikan. Kondisi ini berlangsung selama 32 tahun di masa pemerintahan Presiden Soeharto dan etnis Tionghoa mendapatkan tekanan politik dan sosial untuk berasimilasi.

Kebijakan itu bukannya membuat orang Tionghoa semakin menyatu masyarakat pribumi, tetapi sebaliknya membuat posisi mereka semakin terisolasi. Walaupun orang Cina yang bertempat tinggal di Indonesia dapat mengganti nama mereka dengan nama yang sama dengan pribumi, masih dianggap sebagai warga asing. ketika pasca-1965, terutama setelah rezim militer Orde baru dipimpin Soeharto, diskriminasi terhadap orang-orang Tionghoa semakin terasa. Kebencian pemerintah terhadap orang Tionghoa yang disangkut-pautkan dengan PKI ditularkan secara masif kepada rakyat sehingga pecah kerusuhan anti-Tionghoa di kota-kota besar di Indonesia (Afthonul Afif, 2012: 61).

Kebijakan asimilasi pada masa pemerintahan Orde Baru memberikan dampak pada etnis Tionghoa yang dianggap sebagai bukan pribumi Indonesia dan mereka juga mendapatkan perlakuan diskriminatif serta mendapatkan tindakan keras dan ancaman dalam kehidupan seharihari di Indonesia. Sebaliknya, bagi orang-orang Cina yang tinggal di Madiun 
mereka juga merasakan kebijakan tersebut dari pemerintah pusat, bahwa di dalam kebijakan tersebut pemerintah melarang semua yang berkaitan dengan Cina, seperti bahasa Cina, adat atau kebudayaan Cina yang masuk di Indonesia harus di hapus. Namun, di dalam kehidupan keseharian mereka dengan masyarakat sekitar tetap menjalin hubungan kerjasama yang baik dan Madiun tidak ada kerusuhan ataupun mendapatkan konflik. Sehingga Madiun keadaannya aman.

Adanya persepsi seperti ini, dapat dimengerti bahwa pemerintah Orde Baru berusaha mendiskriminasikan orang-orang Cina dan memberikan tekanan-tekanan terhadap mereka. Dahulu di Madiun ada sekolah Cina yang terletak di jalan Cokroaminoto depan Klenteng dan di jalan Agus Salim yang sekarang digunakan sebagai Perpustakaan Umum Madiun, tetapi setelah adanya kebijakan asimilasi terhadap etnis Cina sekolah-sekolah Cina yang berada di Madiun diambil alih oleh pemerintah. Hal ini merupakan salah satu tekanan dari pemerintah pada bidang pendidikan.

Aspek kebudayaan Cina yang ada di Madiun, yaitu budaya-budaya Cina dan bahasa Cina mendapat diskriminasi oleh pemerintah. Hal ini disebabkan adanya kebijakan asimilasi dari pemerintah Orde Baru pada etnis Cina, termasuk kebudayaan Barongsai dan wayang Tiongkok merupakan hasil kebudayaan asli dari Cina yang dilarang untuk ditampilkan dan diperkenalkan pada masyarakat Madiun.

Pendek kata, kondisi yang terjadi pada orang-orang Cina pada masa pemerintahan Soeharto adalah salah satu kebijakan yang diterapkan di Indonesia, yaitu proses naturalisasi yang ditujukan kepada seluruh orang-orang Cina yang bertempat tinggal lama di Indonesia, termasuk di Madiun. Pada proses naturalisasi ini orang-orang Cina mengganti nama asli mereka dengan nama-nama Indonesia atau nama-nama pribumi, misalnya seperti nama Ang Ciak Jun berganti nama Rudy Siswanto (wawancara dengan Rudy Siswanto, 29 April 2013).

Selanjutnya, pada proses naturalisasi ini membutuhkan dana atau biaya yang cukup besar, sehingga banyak dari orang-orang Cina di Madiun yang ekonominya rendah tidak dapat melanjutkan proses naturalisasi disebabkan kebentur dengan besarnya biaya yang dikeluarkan. Sehingga masih banyak dari mereka yang belum dapat bernaturalisasi di Madiun.

Bulan Mei 1998 di Jakarta dan Solo terjadi kerusuhan yang sangat hebat, dimana dalam kerusuhan itu yang menjadi salah satu korbannya adalah orang-orang Cina. Peristiwa ini terjadi bertujuan untuk meruntuhkan suatu rezim pada masa itu, yaitu rezim Soeharto. Banyak usaha-usaha atau pertokoan-pertokoan yang didirikan etnis Cina dibakar, dirusak, dihancurkan. Adapun bentuk kekerasan fisik dan penindasan terhadap orang-orang Cina yaitu pemerkosaan, pemerasan.

Sebaliknya, keadaan di Madiun justru tidak se-ekstrim yang terjadi di kota-kota besar di Indonesia. Kondisi di Madiun terasa aman dan tidak ada satupun kericuhan dengan penduduk pribumi, tetapi hanya mendapatkan imbas dari peristiwa tersebut, itupun hanya satu hari saja. Di Madiun imbas dari peristiwa Mei 1998 tempat-tempat dagang atau pertokoan-pertokoan milik usaha Cina banyak yang tutup di sepanjang jalan Madiun, namun masih ada sebagian toko yang tetap buka. Sebab 
Madiun tidak mengalami kerusuhan seperti yang terjadi di Jakarta dan Solo dikarenakan di Madiun sendiri militernya sangat kuat, yang diperkuat oleh angkatan darat dan udara yang ada di sekitar Madiun. Sehingga keadaan di Madiun sangat aman pada waktu peristiwa Mei 1998 (wawancara dengan Pramono, 06 Mei 2013).

c) Perkembangan Pada Masa Reformasi

Lahirnya era Reformasi diharapkan mampu membawa perubahan politik yang lebih demokratis. B. J. Habibie mengambil tampuk pimpinan dari Soeharto, muncul berbagai ragam organisasi dan partai-partai politik dalam jumlah yang setiap hari semakin bertambah. Salah satunya adalah Partai Reformasi Tionghoa Indonesia (Parti). Merupakan partai yang pertama kali di era Reformasi ( I. Wibowo dan Ju Lan Thung, 2010: 26). Tetapi pada bulan Mei 1998 terjadi kerusuhan sebagai tumbalnya orangorang Cina. Puncak penindasan mutakhir terhadap etnis Cina terjadi pada huru-hara Peristiwa Mei 1998. Dalam catatan menyebutkan, banyak perempuan Cina dinista, diperkosa, dan dibunuh dalam kekacauan saat itu.

Runtuhnya rezim Soeharto yang terjadi pada masa Orde Baru melahirkan suatu babak baru bagi Indonesia. Terjadi perubahan yang besar terhadap bentuk dan arah pemerintahan. Otoritas penguasa semakin terhimpit dengan merebaknya semangat demokrasi di Indonesia. Reformasi merupakan sebuah masa di mana terjadi perombakan dalam tubuh pemerintahan yang semula bersifat semi absolut atau militeristik menjadi pemerintahan yang berasaskan demokrasi, sehingga masyarakat dapat menyalurkan aspirasinya secara bebas dan bertanggung jawab. Masa reformasi ini berlangsung sejak tahun 1998 hingga sekarang.

Gema Reformasi yang melanda Indonesia ikut memberikan dampak terhadap kehidupan masyarakat Madiun. Hal tersebut tampak pada keberadaan etnis Cina di Madiun yang semakin memiliki aksesbilitas yang tinggi apabila dibandingkan dengan masa Orde Baru. Etnis Cina di Madiun dapat leluasa mengembangkan usaha-usaha yang telah dirintis secara turun-menurun. Semasa kepemimpinan Soeharto mempersempit ruang gerak orang-orang Cina selama di Indonesia, termasuk dalam bidang pendidikan, sosial-budaya mendapatkan diskriminasi. Pasca-Reformasi, orang-orang Tionghoa lebih berani menampilkan jati diri kebudayaan mereka (Afthonul Afif, 2012: 189). Bagi etnis Cina ini merupakan angin segar setelah runtuhnya rezim Soeharto selama tiga dekade.

Masa Reformasi merupakan masa dimana seluruh rakyat dan khususnya orang-orang Cina sebagai warga Indonesia, bebas dan bertanggung jawab untuk menyampaikan aspirasi demi terciptanya kehidupan bangsa yang maju, damai, sejahtera. Ketika pemerintahan Indonesia digantikan dengan Gus Dur atau Abdurahman Wahid. Bagi orang-orang Cina di Indonesia merupakan sebuah cahaya yang terang, disebabkan pada masa pemerintahan Gus Dur menghapus larangan hakhak etnis Cina untuk kembali memperkenalkan adat dan kebudayaan asli negara Cina.

Selanjutnya, Presiden Gus Dur mengakui agama Khong $\mathrm{Hu} \mathrm{Cu}$ yang masuk di Indonesia merupakan sebagian besar agama yang ada di Indonesia. Sebab itu banyak orang-orang Cina yang ada di Madiun mempopulerkan Gus Dur selama menjabat menjadi Presiden. Dengan 
diberikannya kesempatan untuk mengekspresikan identitas kebudayaan mereka, secara tidak langsung pemerintah sebenarnya memberikan kesempatan kepada orang-orang Cina untuk berpartisipasi dalam pembangunan Indonesia (wawancara dengan Rudy Suwanto, 29 April 2013). Rustopo (2007: 78) mengemukakan pendapat bahwa, tokoh Gus Dur sangat populer di kalangan masyarakat Tionghoa, karena semenjak menjadi Presiden, ia menghapus Inpres No. 14/1967 yang isinya melarang masyarakat Tionghoa melakukan adat-istiadatnya.

Pendek kata, pemerintah Gus Dur sudah membuka jalan bagi orang-orang Cina untuk menunjukkan identitas kebudayaan Cina di Indonesia. Melalui kebudayaan asli dari Cina, seperti Barongsai dan wayang Tiongkok mulai diperkenalkan pada masyarakat Indonesia. Di Madiun dalam pertunjukkan kesenian Barongsai masyarakatnya memiliki antusias yang tinggi pada waktu kesenian ini ditampilkan. Sehingga sampai sekarang ini kesenian Barongsai yang ada di Madiun tetap dilestarikan, pada acara-acara tertentu Madiun seringkali menampilkan kesenian Barongsai dan melibatkan orang-orang Jawa pada saat pertunjukkan.

Kesenian Barongsai semenjak pemerintahan Gus Dur sampai sekarang ini mengalami banyak perkembangan. Dalam kesenian Barongsai sekarang ini juga dapat dipelajari oleh anak bangsa Indonesia, tidak hanya orang-orang Cina saja yang mempelajarinya. Di Madiun untuk mempelajari kesenian Barongsai bisa mendapatkan latihan di Klenteng yang berada di jalan Cokroaminoto, bahkan dalam perkembangannya di Madiun kesenian Barongsai juga sudah masuk di kalangan Pondok Pesantren yang ada di Kecamatan Taman Kelurahan Demangan yang bernama Pondok Pesantren Mujaddadiyah, cabang dari Pondok Pesantren ini juga terletak di Kecamatan Kare. Selain kesenian Barongsai kebudayaan Cina yang masuk di Indonesia, yaitu wayang Tiongkok dalam ulang tahun Klenteng ditayangkan selama satu bulan penuh, makanan khas Cina yang disajikan pada saat ulang tahun Klenteng Madiun misalnya Ca Kwe, Kue Goreng, Bakpao yang disajikan untuk kalangan masyarakat umum Madiun secara gratis (wawancara dengan Pramono, 06 Mei 2013).

Berakhirnya kepemimpinan Presiden Abdurahman Wahid atau Gus Dur, pemerintahan Indonesia digantikan dengan Megawati Soekarno Putri. Pada masa pemerintahan Megawati mulai menetapkan tahun baru Imlek sebagai hari libur nasional di Indonesia. Implek merupakan tahun baru bagi kebudayaan Cina, dimana dalam perayaannya dirayakan sangat meriah. Khususnya di Madiun sendiri dalam perayaan malam Tahun baru Implek dirayakan di Klenteng atau tempat peribadatan Tri Dharma.

Selanjutnya, malam perayaan terdapat Lampion-Lampion untuk menghiasi suasana saat malam sebagai adat atau ciri khas dari budaya Cina. Sehingga menjadi suguhan yang menghibur masyarakat Madiun, juga pada sore hari sebelum acara tahun baru sering menampilkan pertunjukkan kesenian Barongsai.

Di era-Reformasi memberikan pengaruh di sektor perekonomian Madiun. Banyak dari orang-orang keturunan Cina mulai mengembangkan beberapa usahanya yang sudah berjalan di Madiun. Banyak keturunan etnis Cina yang berhasil dalam meningkatkan usaha-usahanya di Madiun. Hal ini dapat dibuktikan di daerah kawasan Pecinan yang ada di Madiun 
berfungsi sebagai tempat untuk berdagang dan mendirikan usaha-usaha. Sebagian besar perekonomian di Madiun sekarang ini didominasi oleh keturunan orang-orang Cina di bidang usaha atau perdagangan. Beberapa orang-orang keturunan Cina mendirikan berbagai usaha-usaha di Madiun misalnya, diller motor dan bengkel, toko bangunan, apotek, toko emas, kain, elektronik.

Secara singkat, perkembangan kampung Pecinan di masa sekarang sudah banyak bercampur dengan masyarakat dari berbagai macam etnis seperti Arab, Madura, Jawa, bahkan mereka juga melakukan perkawinan dengan orang-orang pribumi. Semakin berkembangnya tingkat pengetahuan di masyarakat, serta tuntutan dalam memenuhi kebutuhan hidup, di kampung Pecinan ini banyak orang-orang Cina yang mulai mengembangkan usahanya di luar kampung Pecinan dan ada sebagian masyarakatnya yang pindah ke daerah lain atau luar kota untuk mencoba merintis usahanya.

Kampung Pecinan Madiun pada masa Reformasi tidak hanya terpusat di daerah jalan Barito, jalan Kutai, jalan Cokroaminoto, jalan Agus Salim, dan jalan Trunojoyo, namun sekarang ini sudah menyebar di seluruh kawasan di daerah Madiun. Di Kampung Pecinan tempat perdagangan yang paling ramai terletak di jalan Kutai. Disana yang paling banyak mendirikan usaha menjual emas dan perhiasan.

Di kawasan Pecinan sekarang ini masyarakat sudah homogen, tidak bisa dikategorikan sebagai kampung Pecinan murni. Disebabkan banyak dari orang-orang keturunan Cina pindah ke daerah lain untuk mengembangkan usahanya, sehingga di dalam perkampungan ini banyak yang di tempati para pendatang dari luar Madiun dan mendirikan berbagai macam usaha.

\section{Simpulan}

\section{Sejarah Keberadaan Kampung Pecinan di Madiun}

Madiun merupakan kota yang terletak di Provinsi Jawa Timur . Politik Pintu Terbuka yang diperundang-undangkan sejak tahun 1870 yang menanamkan modalnya di Madiun bukan hanya Belanda, tetapi Belanda juga memberikan kesempatan pada orang Asing untuk membuka usaha atau berinvestasi. Pada masa penjajahan Belanda perkampungan Cina ditujukan untuk memudahkan pengawasan dalam usaha perdagangan orang-orang Cina. Sehingga banyak dari orang-orang Cina yang mendirikan bangunan tempat tinggal di sekitar pusat kota.

2. Perkembangan Kampung Pecinan Pada Masa Orde Lama Sampai Dengan Reformasi Di Madiun (Studi Sosial Ekonomi)

a) Pada Masa Orde Lama

Pada masa Orde Lama sistem perekonomian di Indonesia menggunakan sistem perekonomian tertutup. Tindakan diskriminasi terutama ditujukan terhadap orang-orang Asing yang tinggal di Indonesia dan khususnya dilakukan pada etnis Cina, tindakan seperti ini sering disebut dengan sistem Benteng. Untuk masyarakat Madiun di sekitar kampung Pecinan terjadi hubungan yang damai dan harmonis. Orangorang Cina yang menempati kampung ini mereka dapat membaur dengan 
masyarakat pribumi, sehingga tidak pernah terjadi konflik antara pribumi dengan orang-orang Cina di Madiun.

b) Pada Masa Orde Baru

Pergantian Orde Lama bersamaan dengan runtuhnya suatu rezim, yaitu rezim Soekarno, yang dulunya di dalam kebijakan ekonomi mengalami ketertutupan yang berorentasi sosialis kemudian mengalami perubahan menjadi ekonomi terbuka yang berorentasi kapitalis pada pemerintahan Soeharto. Pemerintah memperkenalkan kebijakan asimilasi yang ditunjukkan pada etnis Cina. Tiga pilar budaya Tionghoa yaitu organisasi Tionghoa, media Tionghoa dan sekolah Tionghoa dilarang pemerintah dan orang Tionghoa harus di Indonesiakan atau dipribumikan di Madiun.

c) Pada Masa Reformasi

Masa Reformasi merupakan masa dimana seluruh rakyat dan khususnya orang-orang Cina sebagai warga Indonesia, bebas dan bertanggung jawab untuk menyampaikan aspirasi demi terciptanya kehidupan bangsa yang maju, damai, sejahtera. Hal tersebut tampak pada keberadaan etnis Cina di Madiun yang semakin memiliki aksesbilitas yang tinggi apabila dibandingkan dengan masa Orde Baru. Etnis Cina di Madiun dapat leluasa mengembangkan usaha-usaha yang telah dirintis secara turun-menurun.

\section{Saran}

1. Bagi Masyarakat Umum di Madiun Diharapkan kepada masyarakat Madiun untuk tetap menjaga kerukunan antar umat beragama, etnis, sebab dengan adanya kerukunan antara orangorang pribumi dengan orang-orang keturunan Cina, serta dengan suku bangsa yang ada di sekitar Madiun akan terciptanya kehidupan yang harmonis.

2. Bagi Masyarakat Sekitar Kawasan Pecinan

Untuk masyarakat sekitar supaya selalu menjunjung tinggi dan melestarikan kebudayaan masing-masing yang ada di kawasan Pecinan. Sebab kebudayaan merupakan peninggalan dari nenek moyang yang wajib dilestarikan.

3. Bagi Pemerintah Kelurahan Pandean dan Pemerintah Kota Madiun

Pemerintah tetap memberikan kemudahan dalam pelayanan kepada seluruh masyarakatnya dalam perizinan atau memberikan kemudahan fasilitas kepada masyarakat.

\section{Daftar Pustaka}

Afthonul Afif. 2012. Identitas Tionghoa Muslim Indonesia Pergulatan Mencari Jati Diri. Depok: Kepik

Agasty. 2011. Agastya Jurnal Sejarah dan Pembelajarannya. Madiun: Prodi Pendidikan Sejarah IKIP PGRI Madiun 
Asmadi Alsa. 2004. Pendekatan Kuantitatif \& Kualitatif Serta Kombinasinya Dalam Penelitian Psikologi. Yogyakarta: Pustaka Pelajar

Black A. James dan Champion J. Dean. 2009. Metode dan Masalah Penelitian Sosial. Bandung: Refika Aditama

Budi A. Sukada. 2007. Semarang Tempo Dulu Teori Desain Kawasan Bersejarah. Yogyakarta: Ombak

Dadang Supardan. 2008. Pengantar Ilmu Sosial Sebuah kajian Pendekatan Struktural. Jakarta: PT Bumi Aksara

Deddy Mulyana. 2007. Ilmu Komunikasi Suatu Pengantar. Bandung: PT Remaja Rosdakarya

Emzir. 2011. Metodologi Penelitian Kualitatif Analisis Data. Jakarta: PT RajaGrafindo Persada

Herlianto. 1986. Urbanisasi dan Pembangunan Kota. Bandung: PT. Alumni

Husaini Usman dan Purnomo Setiady Akbar. 2003. Metodologi Penelitian Sosial. Jakarta: PT Bumi Aksara

I. Wibowo dan Ju Lan Thung. 2010. Setelah Air Mata Kering Masyarakat Tionghoa Pasca-Peristiwa Mei 1998. Jakarta: Buku Kompas

Ida Bagoes Mantra. 2003. Demografi Umum. Yogyakarta: Pustaka Pelajar

J. Babari dan Albertus Sugeng. 1999. Diskriminasi Rasial Ethnis Tionghoa di Indonesia. Jakarta: Fatma Press

Kwik Kian Gie. 1999. Ekonomi Dalam Krisis dan Transisi Politik. Jakarta: PT. Gramedia Pustaka Utama

Leo Suryadinata, Evi Nurvidya Arifin, Aris Ananta. 2003. Penduduk Indonesia Etnis dan Agama Dalam Era Perubahan Politik. Jakarta: Pustaka LP3ES Indonesia

Leo Suryadinata. 1990. Mencari Identitas Nasional Dari Tjoe Bou San Sampai Yap Thiam Hien. Jakarta: LP3ES

Leo Suryadinata. 1999. Etnis Tionghoa dan Pembangunan Bangsa. Jakarta: Pustaka LP3ES Indonesia

Miles dan Hubermen. 1992. Analisis Data Kualitatif. Jakarta: Universitas Indonesia

Onghokham. 2011. Asia Tenggara Dalam Kurun Niaga 1450-1680. Jakarta: Yayasan Pustaka Obor Indonesia

Pemerintah Kabupaten Daerah Tingkat II Madiun. 1980. Sejarah Kabupaten Madiun. Madiun

Poespoprodjo. 1986. Jejak-jejak Sejarah 1908-1926 Terbentuknya Suatu Pola. Bandung: CV Remadja Karya

Pratiwo. 2010. Arsitektur Tradisional Tionghoa dan Perkembangan Kota. Yogyakarta: Ombak

R. Moh. Ali. 1963. Pengantar Ilmu Sedjarah Indonesia. Jakarta: Batara

Rustopo. 2007. Orang-Orang Tionghoa dan Kebudayaan Jawa. Yogyakarta: Ombak

Saefur Rochmat. 2009. Ilmu Sejarah Dalam Perspektif ILmu Sosial. Yogyakarta: Graha Ilmu

Saifuddin Azwar. 2004. Metode Penelitian. Yogyakarta: Pustaka Pelajar

Selo Soemardjan. 1988 . Masyarakat dan Kebudayaan. Jakarta: Djambatan

Soekisman. 1975. Masalah Cina di Indonesia. Jakarta: Yayasan Penelitian Masalah Asia

Suharsimi Arikunto. 2010. Prosedur Penelitian Suatu Pendekatan Praktik. Jakarta: PT. Rineka Cipta

Suherman Rosyidi. 2011. Pengantar Teori Ekonomi Pendekatan Kepada Teori Ekonomi Mikro \& Makro. Jakarta: PT. RajaGrafindo Persada 
Sukisman. 1993. Sejarah Cina Kontemporer (Dari Revolusi Nasional Melalui Revolusi Kebudayaan Sampai Modernisasi Sosialis). Jakarta: PT. Pradnya Paramita Supardi. 2011. Dasar-Dasar Ilmu Sosial. Yogyakarta: Ombak

Trianto. 2010. Pengantar Penelitian Pendidikan Bagi Pengembangan Profesi Pendidikan Tenaga Pendidikan. Jakarta: Prenada Media

Tubagus P. Svarajati. 2012. Pecinan Semarang dan Dar-Der-Dor Kota. Semarang: Suku Buku

Winardi. 1966. Kamus Ekonomi (Inggris-Indonesia). Jakarta: Alumni 